\title{
THE INCREASE OF PERFORMANCE OF AN ENTITY BY THE CONVERSION OF THE HIDDEN COSTS
}

\author{
Sorin Briciu ${ }^{1}$ \\ Sorinel Căpuşneanu ${ }^{2}$
}

\begin{abstract}
This article offers an intrinsic image of the hidden and identified costs at the level of an entity, including the causes and their ways of control. The main research instrument used here was the questionnaire and the results determined a better knowledge of the theoretical and methodological aspects necessary in order to identify the hidden costs at the level of an entity. Several aspects of the hidden costs are discussed, as well as their characteristics, evaluation, causes and generating sources. The connections between disfunctionalities, the generating factors of the hidden costs and their financial components are presented in theory and represented in graphics. The article closes with the authors' conclusions on the identification, determination, conversion and presentation in a situation of synthesis of the hidden costs of an entity, as well as the importance managers should grant to it.
\end{abstract}

Keywords: hidden costs, Activity-Based Costing, control, performance, opportunity costs.

JEL codes: M21, M41

\section{Introduction}

\section{The background of the study}

In the present stage when all entities, regardless their size and their areas of interest are confronted with problems in maintaining the costs and obtaining benefits, considering the changes caused by the competition, the issue of the hidden costs can prove its priority and importance in discovering the causes and eliminating the hidden provoked by them. In writing this article we started from the identification of the hidden costs and the study of their effects on the performance of an entity, including the ways of controlling them. The interconnectivity between the hidden costs and the hidden performances is proven following the studies done within entities in Romania.

\section{Goal and objectives}

Because the national and international professional literature could not provide a complete list of the hidden costs of an entity, our goal is to try and identify their types, their causes and ways of con troll following the studies done within some entities in Romania. This article addresses to all the managers and professionals interested in elaborating a document able to reflect next to the information presented and attached to a balance sheet or results account also a situation of the hidden costs. As the identification of the hidden costs is closely linked to the achievement of superior performances within the entity, we consider it extremely important to study them in the present context, especially as every entity, regardless of its size, is confronted in one or another way with losses, and the causes of these losses can be identified and even prevented and eliminated. We shall try to offer a starting model in editing and concentrating the necessary information needed for complex analyses form the heads of departments and from the managers of organizations.

\footnotetext{
1 “1 Decembrie 1918” University, Faculty of Science, Alba Iulia, Romania, e-mail: sbriciu@yahoo.com

${ }^{2}$ Artifex University, Bucharest, Romania, e-mail: sorinelcapusneanu@gmail.com
} 


\section{Professional literature}

A special contribution to the study of hidden costs is brought by Henri Savall and his team of research, the results of which were made public in France through the intermediary of ISEOR ${ }^{3}$ and which constituted the starting point for several discussions in the academic and business environment. We can also mention here the various studies conducted by independent companies the results of which were made public, being used only for internal analyses on a managerial or interdepartmental level.

\section{Research and methodology}

\section{Research questions}

This article intends to explore out attempt to identify, analyze and control the hidden costs of an entity. In this respect we measured the judgment of the professionals from the area of managerial accounting in Romania, as well as that of managers from various state owned and private entities. We tried to find answers to the following questions:

1. Is it possible to identify hidden costs at the level of each entity regardless its size?

2. Can the generating causes of hidden costs be identified?

3. Can hidden costs be controlled?

4. Can we elaborate a relevant document for the outline and analysis of hidden costs?

\section{Instruments}

Research planning is focused on the theoretical approach of the implications determined by the development in the issues described by the questions launched at the beginning of the study. For the relevance of the study we used the following instruments: induction, deduction, as well as questionnaires for which three large categories of subjects were considered. The first category is made of specialists from the area of accounting (management accountants), the second category is represented by managers of entities (heads of departments, upper management etc.) and the last category, maybe the most important of all, the personnel hired in the entities.

\section{Proof and data analysis}

The above sample was elaborated on a number of 735 persons, according to the above mentioned categories. Following the centralization of the data, the situation is as follows (table no.1):

Table no.1.

Category of respondents

\begin{tabular}{|l|c|c|c|}
\hline \multirow{2}{*}{ Voting option } & \multicolumn{3}{|c|}{ Category of respondents } \\
\cline { 2 - 4 } & Accounting professionals & Managers of entities & Hired staff \\
\hline For & $94,96 \%$ & $81,90 \%$ & $66,12 \%$ \\
\hline Against & $5,04 \%$ & $18,10 \%$ & $33,88 \%$ \\
\hline Total & $100 \%$ & $100 \%$ & $100 \%$ \\
\hline
\end{tabular}

As one can notice, the largest percentage from the three categories questioned plead for the identification, analysis and combating of hidden costs. Starting from this situation, our empirical study continued and the results gathered following the identification, analysis and presentation of the preventive measures are described in the following.

\section{Hidden costs. Conceptual approaches, characteristics, evaluation, causes}

In the national and international professional literature there were a series of approaches or definitions of the notion of hidden costs which we shall try to present through the prism of identifications done by the means of informational systems at the level of managerial accounting

\footnotetext{
${ }^{3}$ Socio Economic Institute of Firms and Organizations
} 
and the factors that lead to their apparition or starting at the level of an entity. In time, hidden costs have had various names like: disfunctionality costs, uncertain costs etc. These hidden costs may result from the difference between the real functioning of the entity and its ideal functioning ${ }^{4}$ under normal circumstances. Hidden costs are expenses ${ }^{5}$ which are normally not included in the acquisition price of equipment (machine).

At the level of managerial accounting we can identify the following hidden costs: opportunity costs (costs of lost occasions, costs of some unachieved profits), environmental (green) costs, under-activity costs, etc. In our opinion, a hidden cost represents that cost that does not appear explicitly in the informational system of the entity, whether we speak about the budgets system, financial accounting or management accounting. Hidden costs do not allow for a quantification of results and deviations, but may allow for an analysis of the ensemble of causes at their origin as a phenomenon being closely linked to the quality of the functionality of an entity.

The social and economic theory of organizations underlines the quality of the functioning of the entity or, in other words, the capacity of productive entities to manage their material, physical, monetary and human resources. Such an approach allows us to stress the factors that constantly perturb the life of the entity and which refer to certain abnormalities or difficulties of functioning (and the economic appearance of which must be evaluated) which hider the entity from reaching its objectives efficiently, representing a loss of resources. An entity will react to these generating factors of hidden costs through certain actions of correction, measures which will require certain costs. These costs may refer to losses of production due to functionality of an inferior level that programmed, to rejects, to supplementary expenses with wages etc. From this perspective, hidden costs can be defined as monetary quantification of corrective actions.

The characteristics of visible costs and of hidden costs can be represented as follows (table no.2):

Table no. 2 .

\section{Differences between visible costs and hidden costs}

\begin{tabular}{l} 
Visible costs \\
\hline - can be measured at the level of the \\
entity \\
- can be named by direct identification \\
- can be tracked in accounting
\end{tabular}

- have a direct impact on the performances of an entity

\begin{tabular}{l}
\hline Hidden costs \\
\hline - can not be measured at accounting level or are \\
sometimes incorporated within visible costs \\
- cannot be named by direct identification \\
- cannot be supervised (tracked) or are left \\
intentionally unregistered within visible costs \\
- have a direct impact on the performances of an \\
entity product quality, direct \\
- generating factors: absenteeism, work accidents, \\
personnel rotation, product \\
productivity.
\end{tabular}

The evaluation of hidden costs id done as follows:

1. Over-wages are generated by absenteeism, determined in its turn by wages deviations of the additional personnel or by staff changes, when managers overtake the attributions of their subordinates. This way the entity is forced to pay certain bonuses for this supplementary duty by the management or by other executive organs. Its general causes may be: functions change due to absenteeism or lack of personnel, the management takes over tasks due to the overloaded tasks of their subordinates etc.

\footnotetext{
${ }^{4}$ Allows for the achievement of its goals, considering the social, psychological, individual or collective constraints of the hired staff.

${ }^{5}$ Expenses of maintenance, consumables, training, renewal etc.
} 
2. Overtimes are generated by some activities within the entity that do not generate value. They generate costs due to the fact that the infrastructure and work equipments of the entity are not properly used. The causes are due to: errors, useless activities (useless procedures), lack of precise information (lack of organization and information), distractions (lack of weekly information and analysis meetings), inefficiency of work equipments (planning of reparations during the work time, the use of old equipments) etc.

3. Over-consumes are generated by those consumes that could have been avoided. Their causes are due to: errors, excessive use of rough materials and energy, squandering etc.

4. Non-production is represented by interruption or cease of an activity related to a malfunction. Among he caused there have been identified: slower production (delays in the chain of production, wasted time), interruption of production (week functioning of the machined used) etc.

5. Non-value is represented by the lack of potential creation generated by the lack of orientation towards investments due to the major involvement in tracking malfunctions and insufficient time for investment activities. The general causes are due to the loss of market share or knowledge (know-how).

\section{Generating sources of hidden costs and their conversion}

The origin of hidden costs represents a very important issue that deserves to be looked into. Also, the economic and financial professional literature has to be studied especially from the microeconomic level. This way, an organization is considered to be made of an ensemble of interactions between different structures and behaviors. According to the specialists' opinion we may identify the following generating factors of hidden costs at the level of the entity:

1. Malfunctions (work conditions, work organization, communication, coordination, research, time management);

2. Behaviors (individual, group, collectivity, pressure groups);

3. Structures (physical, technological, organizational, demographic, and mental).

From the graphic point of view (fig. no.1), the structural factor that determines the apparition of hidden costs is presented as follows:

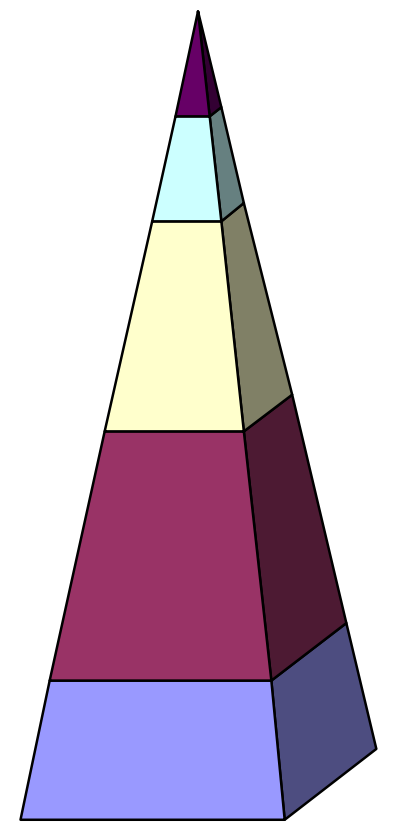

Mental structure (Managerial style, microclimate of the entity, social and cultural concept)

$\square$ Physical structure (Physical space, place configuration, perturbing factors)

$\square$ Demographic structure (Adjustment of staff, pyramidal age and work force structure, continuous training, structure of qualifications, promotion and professional channels, recruitment policy)

$\square$ Organizational structure (Organizational diagram of the entity, diagram of social organization of the entity, labor division, operational methods, work program and types, procedures, research system, coordination and communication, operational and functional information)

$\square$ Technological structure (Amortization level life span of the machines, complexity and automatization, adaptability of equipment to the manufacturing requirements, concordance between incidents between training and workplace)

Figure no. 1.- The pyramid level of the structural factor

From the graphic point of view (fig. no. 2), the relation between malfunctions, generating factors of hidden costs and financial components of generating factors is presented as follows: 


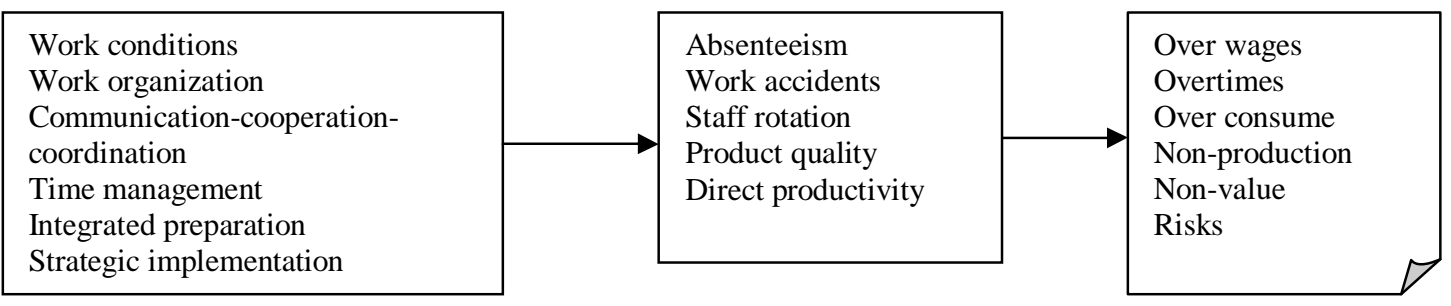

Figure no. 2.- Connections between malfunctions, generating factors of hidden costs and their financial components

The hidden cost can be presented in the form of the following general calculation relation (fig. no.3):

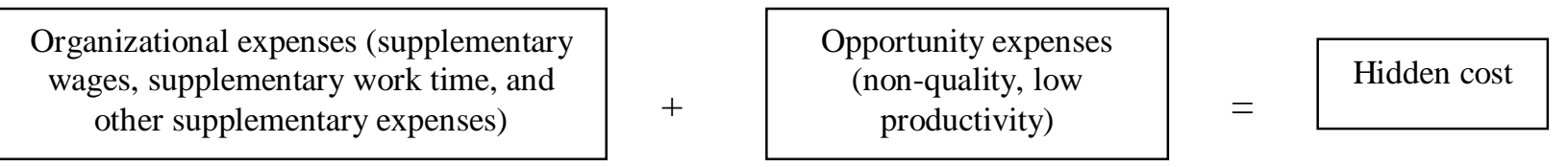

Figure no. 3. The calculation relation of hidden costs

Organizational expenses are made of historical costs like:

1. Supplementary wages expenses refers to unjustified wages received by some employees who did not fulfill their tasks and this is due to absenteeism or work accidents;

2. Expenses with supplementary work time refers to the unjustified remuneration of employees who have been involved in a process of planning, remaking or rearrangement of some products rejected because of their poor quality;

3. Other supplementary expenses refer to those expenses generated by malfunctions or extension of the supplementary time, of rejections (for instance: expenses with electrical energy, water, fuel or rough materials etc.).

Opportunity expenses refer to the losses an entity has to bear. These losses can be generated by products of inferior quality or by low productivity (non-production or decrease of production). The real loss can be reflected by the low amount of sales, of product volume, but also of result (low profit). The decrease of productivity implies a restraint of the sold products and therefore, the profit will be just as low.

Classic informational systems identify in a very small amount the hidden costs or even do not identify them at all. Hidden costs, although determined by known and visible causes, have an invisible size as they are included in the costs. As we have notices, hidden costs do not present any of the characteristics of visible costs and therefore we can not isolate their real size, but we may only identify and analyze their causes.

The method "Costs - hidden performances" proposed by H. Savall in 1993 and developed further within ISEOR (Economic and Social Institute of Enterprises and Organizations) suggests that an efficient management can be done only by agreeing upon the economical and social dimensions of a company by the means of this method. The general calculation model for the hidden costs proposed by H. Savall is as follows (table no. 3): 
Table no. 3 .

The general calculation model for hidden costs

\begin{tabular}{|c|c|c|c|c|c|c|}
\hline \multirow[t]{2}{*}{ Indicators } & \multicolumn{3}{|c|}{ Over-expenses } & \multicolumn{2}{|c|}{ Opportunity costs } & \multirow[b]{2}{*}{ Total } \\
\hline & Over-wages & Overtimes & Over-consume & Non-production & Non-value & \\
\hline \multicolumn{7}{|l|}{ Absenteeism } \\
\hline \multicolumn{7}{|l|}{ Work accidents } \\
\hline \multicolumn{7}{|l|}{ Staff rotation } \\
\hline \multicolumn{7}{|l|}{ Product quality } \\
\hline \multicolumn{7}{|l|}{ Productivity deviations } \\
\hline Total & & & & & & \\
\hline
\end{tabular}

Source: After Savall H., Zardet V., Bonnet M. „Releasing the untapped potential of enterprises through socioeconomic management", $2^{\text {nd }}$ revised publication, June, 2008, p. 55.

\section{Example of determining the hidden costs}

At the beginning of the year an entity that produces washing machines sets a planned budget that comprises: incomes 960,000 RON and expenses 912,000 RON, profit 48,000 RON. During the year expenses get higher and incomes decrease due to malfunctions, and the effective result account is as follows: incomes 960,000 RON, expenses 912,000 RON, deficit $12.000 \mathrm{RON}$. This way the hidden costs are of 48,000 RON (non-income). The saved expenses are of $35 \%$ from 48,000 RON, this is $16,800 \mathrm{RON}$. If it had not been for the over-expenses related to malfunctions, effective expenses should have been: 912,000 RON $-14,400$ RON $=897,600$ RON. Over-expenses $=$ $924,000 \mathrm{RON}-897,600 \mathrm{RON}=26,400 \mathrm{RON}$. This way the hidden costs are of 48,000 RON + $26,400 \mathrm{RON}=74,400 \mathrm{RON}$.

The results account (table no. 4) is as follows:

Table no. 4.

The results account situation

\begin{tabular}{|l|r|l|r|r|}
\hline \multicolumn{1}{|c|}{ Explanations } & $\begin{array}{c}\text { Amount } \\
\text { (RON) }\end{array}$ & Explanations & \multicolumn{1}{|c|}{$\begin{array}{c}\text { Amount } \\
\text { (RON) }\end{array}$} \\
\hline Visible expenses & 897,600 & Visible results & 912,000 \\
\hline Hidden costs of malfunctions, from which: & 74,400 & Non-products & 48,000 \\
\hline - hidden over-expenses & 26,400 & Forecasted results & 960,000 \\
\hline - non-products & 48,000 & Deficit & 12,000 \\
\hline \multicolumn{1}{|c|}{ Total } & 972,000 & & 972,000 \\
\hline
\end{tabular}

What represents the conversion of hidden costs? Cost conversion represents the process by which hidden costs, once identified and evaluated, are tried to be recovered to a certain extent in order to contribute to better economic performances. How is conversion done? Starting from the example above, the entity makes an investment in an informational program and the situation is as follows (table no. 5):

Table no. 5 .

The situation after investment

\begin{tabular}{|l|c|c|}
\hline & Explanations & $\begin{array}{c}\text { Value } \\
\text { (RON) }\end{array}$ \\
\hline 1. New informational system & 3,000 \\
\hline 2. Training time for the employees & 6,000 \\
\hline 3. Total cost of gained potential creation & 9,000 \\
\hline
\end{tabular}

The conversion of hidden costs into the added value due to potential creation (table no. 6) is done as follows: 
Table no. 6.

Conversion of hidden costs into the added value

\begin{tabular}{|c|c|c|c|}
\hline Impact of creating gained potential & $\begin{array}{c}\text { Annual hidden } \\
\text { costs }\end{array}$ & $\begin{array}{l}\text { Conversion rate of hidden } \\
\text { costs into added value }\end{array}$ & $\begin{array}{c}\text { Expected hidden } \\
\text { annual performances }\end{array}$ \\
\hline 1. Products of poor quality & 3,300 & $2 / 3$ & 2,200 \\
\hline $\begin{array}{l}\text { 2. Metallic carcasses deteriorated } \\
\text { during the packing process }\end{array}$ & 1,200 & $2 / 3$ & 800 \\
\hline 3. Product overload & 3,000 & $1 / 3$ & 1,000 \\
\hline $\begin{array}{l}\text { 4. Time wasted with repairs, } \\
\text { maintenance and cleaning the machines } \\
\text { due to the employees' negligence }\end{array}$ & 1,000 & $3 / 3$ & 1,000 \\
\hline $\begin{array}{l}\text { 5. Useless intervention due to operating } \\
\text { errors }\end{array}$ & 1,500 & $2 / 3$ & 1,000 \\
\hline Total & 10,000 & $60 \%$ & 6,000 \\
\hline
\end{tabular}

From this point of view, the calculation of the period of return of investment by creating potential and the produces impact are as follows (table no. 7):

Table no. 7.

\section{Calculation of the period of return of investment}

\begin{tabular}{|c|l|l|}
\hline \multicolumn{1}{|c|}{ Explanations } & \multicolumn{1}{|c|}{ Costs } & \multicolumn{1}{|c|}{ Performances } \\
\hline $\begin{array}{c}\text { Visible costs and } \\
\text { performances }\end{array}$ & $\begin{array}{l}\text { Purchasing new informational } \\
\text { program 3,000 RON }\end{array}$ & $\begin{array}{l}\text { Increase of productivity with 3,000 RON per } \\
\text { year }\end{array}$ \\
\hline $\begin{array}{c}\text { Hidden costs and } \\
\text { performances }\end{array}$ & $\begin{array}{l}\text { Investments in training time for the } \\
\text { employees 6,000 RON }\end{array}$ & $\begin{array}{l}6,000 \text { RON conversion of hidden costs into } \\
\text { added value }\end{array}$ \\
\hline \begin{tabular}{c|l|l|} 
Hidden quantitative and \\
qualitative data
\end{tabular} & $\begin{array}{l}\text { He need to define new quality } \\
\text { standards }\end{array}$ & $\begin{array}{l}30 \% \text { increase in customer satisfaction due to an } \\
\text { improvement in production quality }\end{array}$ \\
\hline Total & 9,000 RON & 6,000 lei + increase in customer satisfaction \\
\hline Annual costs/performances & $9,000 / 3=3,000$ RON & \\
\hline Return period & 2 months \\
\hline
\end{tabular}

\section{Situations for reporting of dysfunction analysis}

Following the identification, analysis and conversion of hidden costs one can draw a series of situations meant to stress how often they appear, to identify the causes or the impact on economic performances (table no. 8 and table no. 9). These can be presented in the following forms:

\section{Analysis of dysfunctions from the point of view of the economic impact produced by}

Table no.8. hidden costs

\begin{tabular}{|c|c|c|c|}
\hline $\begin{array}{c}\text { Name of the hidden } \\
\text { cost }\end{array}$ & Frequency & Identification of causes & $\begin{array}{l}\text { Economic impact produced by the } \\
\text { hidden cost }\end{array}$ \\
\hline Absenteeism & Monthly & Time management & Over-wages \\
\hline Staff rotation & Quarterly & $\begin{array}{l}\text { Integrated training } \\
\text { Strategic implementation }\end{array}$ & $\begin{array}{l}\text { Overtimes } \\
\text { Over-consume }\end{array}$ \\
\hline $\begin{array}{l}\text { Work accidents and } \\
\text { professional diseases }\end{array}$ & Monthly & & $\begin{array}{l}\text { Non-production } \\
\text { Non-value }\end{array}$ \\
\hline Product quality & Monthly & & $\begin{array}{l}\text { Risks } \\
\text { Work conditions } \\
\text { Work organization }\end{array}$ \\
\hline Productivity deviations & Monthly & & Communication-cooperation-coordination- \\
\hline
\end{tabular}


Table no. 9.

Analysis of dysfunctions from the point of view of the impact on economic performances

\begin{tabular}{|c|c|c|c|c|}
\hline $\begin{array}{c}\text { Dysfunctional } \\
\text { cost noticed }\end{array}$ & $\begin{array}{c}\text { Frequency of } \\
\text { occurrence }\end{array}$ & $\begin{array}{c}\text { Identification } \\
\text { of causes }\end{array}$ & $\begin{array}{c}\text { Confirmed economic impact } \\
\text { (components of financial } \\
\text { consequences) }\end{array}$ & $\begin{array}{c}\text { Impact on economic } \\
\text { performances } \\
\text { (components of hidden } \\
\text { costs) }\end{array}$ \\
\hline & & & & \\
\hline & & & & \\
\hline & & & & \\
\hline & & & & \\
\hline
\end{tabular}

The situations presented can be put together and analyzed within some synthesis accounting documents like the results account (Căpuşneanu S., Briciu S., 2011), the annexes of the results account and together with other situations as well ( Cokins G., et all, 2011).

\section{Conclusions}

Considering all the aspects mentioned above about hidden costs and their importance in the management of financial resources and in achieving performances by any entity, we plead for the concentration of their specific information within the accounting synthesis documents that lay at he basis of managerial decisions. The impact produces by hidden costs on the performances of an entity has to be more emphasized in the internal analyses in order to discover their types and causes, including the actions for their conversion. The two situations proposed for analysis of the hidden costs bring extra information necessary in substantiation of managerial decisions and their conversion for increasing the performance of an entity. The aspects presented and interpreted here represent a point of view that deserves to be analyzed and treated within the professionals" discussions and we would like to have a larger analysis area of these hidden costs by the extension of professional collaborations and by the gradual and continuous mediatization of the results of scientific research in this still unexplored yet full of solutions area, that could bring a fresh air in cost management and achievement of higher performances.

\section{References}

1. Basics P.D., 1999. The hidden costs of Networked Learning - The consequences for university administrators. Paper presented at International Meeting of University Administrators, Edinburgh: September.

2. Briciu S., Căpuşneanu S., Rof L.M., Topor D., 2010. Accounting and management control. Entity performance assessment tools, Aeternitas Publishing House, Alba-Iulia.

3. Briciu S., 2006. Management accounting. Theoretical and practical aspects, Economic Publishing House, Bucharest.

4. Căpuşneanu S., 2009. Elements of cost management, Economic Publishing House, Bucharest

5. Căpuşneanu S., Briciu S., 2011. Control and analysis of costs based on results account of the ABC method, International Journal of Academic Research in Business and Social Sciences, October, Vol. 1, No. 3, pp. 146-147.

6. Cokins G., Căpuşneanu S., Barbu C.M., 2011. Decisions based on synthesis documents information of the ABC (Activity-Based Costing) method, International Journal of Accounting and Financial Reporting, Vol. 1, no. 1, , pp. 119-125

7. Falk A. M., Kosfeld M., 2004. Distrust - The Hidden Cost of Control, June.

8. Fehr, E., List, J.A., 2004. The hidden costs and rewards of incentives Journal of the European Economic Association forthcoming.

9. Savall H., Zardet V., Bonnet M., 2008. Releasing the untapped potential of enterprises through socio-economic management, $2^{\text {nd }}$ revised publication, June, pp. 30-138. 